\title{
ALPHA-FETOPROTEIN AS A BIOCHEMICAL DIAGNOSTIC AND PROGNOSTIC MARKER FOR PROLONGED JAUNDICE IN NEWBORNS
}

\author{
O. H. MAZUR, O. S. YABLON, O. S. RUBINA, \\ M. M. PUHACH, A. P. KONOPLITSKA \\ National Pirogov Memorial Medical University, Vinnytsia, Ukraine; \\ e-mail: alena523@ukr.net
}

Received: 14 January 2019; Accepted: 13 August 2019

Prolonged jaundice of newborns is a common pathology during the neonatal period. Recently, there has been a tendency toward an increased number of newborns with prolonged jaundice with duration longer than 14 days of life. According to the polyetiologic nature of neonatal jaundice, it is necessary to investigate new diagnostic signs that can predict the development of prolonged jaundice in newborns and, allow identification of new methods of differential diagnosis of neonatal jaundice, as well as decrease the frequency of this pathology. The parameters of serum alpha-fetoprotein (AFP) content in newborns with prolonged jaundice were studied. The content of AFP in blood serum was 1.7 times higher in newborns with prolonged jaundice than in newborns with jaundice for up to 14 days of life: $M e=671.1$ [Q1 $=479.9 ; \mathrm{Q} 3=815.03] \mathrm{ng} / \mathrm{ml}$ and $\mathrm{Me}=401.0[\mathrm{Q} 1=284.9 ; \mathrm{Q} 3=684.0] \mathrm{ng} / \mathrm{ml}$, respectively $(P<0.05)$. The content of blood serum AFP in newborns with prolonged jaundice was higher for total serum bilirubin greater than $250 \mu$ mole/l: Me $=626.2$ $[Q 1=454.7 ; Q 3=793.2] \mathrm{ng} / \mathrm{ml}$ which was confirmed by a strong direct correlation relationship $\left(r_{x y}=0.64\right.$, $P<0.05)$. The results of the ROC analysis confirmed that AFP $\geq 571.7 \mathrm{ng} / \mathrm{ml}$ can identify newborns with prolonged jaundice with a sensitivity of $74.2 \%$ and a specificity of $74.5 \%$. The area under the curve (AUC) was 0.870 (95\% CI 0.804, 0.937), which confirms the good quality of the AFP model $\geq 571.7 \mathrm{ng} / \mathrm{ml}$.

Ke y w o rd s: alpha-fetoprotein prolonged jaundice, newborns, bilirubin, .

$\mathrm{N}$ eonatal jaundice occurs in $50 \%$ of term and $80 \%$ of preterm newborns all over the word [1]. Jaundice is one of the most common causes of neonatal readmission to hospital, especially during the first 2 weeks after birth. The icteric color in most newborns may accompany postnatal adaptation, but may also be a manifestation of the pathological accumulation of serum bilirubin.

Of particular note are jaundices with a prolonged course, when term newborns remains clinically jaundiced at 14 days of postnatal life or after 21 days in premature newborns. Up to $30-40 \%$ of breastfed newborns remain jaundiced for the first 3 to 4 weeks of life [2-3]. The most common cause is breast milk jaundice which is characterized by a satisfactory state of newborns, normal physical development and in most cases does not require medi- cal intervention. This type of jaundice is diagnosed by excluding other pathological conditions and, a number of disease processes including haemolysis, sepsis, hypothyroidism, cystic fibrosis, metabolic disease and liver disease (mainly congenital hepatitis B/C or biliary atresia) [4-6].

The risk of the development of indirect hyperbilirubinemia of prolonged genesis is necessary to predict, since newborns are discharged from the hospital at the peak of physiological jaundice. Prolonged hyperbilirubinemia of greater than 2 to 3 weeks duration requires additional investigation [7-10].

Excessive accumulation of unconjugated bilirubin in the blood can potentially lead to acute and chronic bilirubin encephalopathy (kernicterus) or can lead to long-term complications such as cerebral palsy or neuropathy of the auditory analyzer [11, 12].

(C) 2019 Mazur O. H. et al. This is an open-access article distributed under the terms of the Creative Commons Attribution License, which permits unrestricted use, distribution, and reproduction in any medium, provided the original author and source are credited. 
There is also evidence that excessive accumulation of unconjugated bilirubin in the blood can lead to disturbances of intestinal microbiocynosis, which is due to the anatomical and physiological features of the digestive tract of newborns: the absence of specific microflora contributing to the conversion of indirect bilirubin to sterkobilin, as well as the connection of the hepatobiliary system and the intestine (enterohepatic circulation) [13-16].

An analysis of the foreign medical literature indicates that the severity and duration of indirect hyperbilirubinemia is determined by etiological and pathogenetic features and requires a differentiated approach to the diagnosis and treatment of neonatal jaundice, as well as optimization of the prevention of adverse factors that can lead to a decrease in the frequency of this pathology [17].

Foreign studies have shown ambiguous effects of serum alpha-fetoprotein (AFP) on the development of prolonged jaundice in newborns. AFP, by its physical and chemical properties, is similar to the main protein of blood serum, namely albumin. AFP has long been used as a marker in prenatal diagnosis for the detection of developmental fetal defects and as a cancer marker in malignant neoplasms [18].

However, the mechanisms of a postnatal increase in AFP remain unexplained, but possibilities include an increased rate of synthesis in the liver, or prolonged half-life due to altered clearance of blood. During the first year of life, AFP gradually ceases to be synthesized by the liver and is completely eliminated from the body of the child by two years. An increase in the AFP content by $95.0 \%$ or prolonged preservation of its synthesis after birth can indicate liver damage. Determination of the content of AFP would allow establishment of the mechanisms of the prolonged jaundice in the early stages of its development and would broaden the thinking of pediatricians, neonatologists, and family physicians about the peculiarities of the course of prolonged jaundice in newborns [19].

Thus, the purpose of this study was to determine the role of serum AFP levels in newborns with prolonged jaundice.

\section{Materials and Methods}

This prospective study was performed in the neonatology unit of the Regional Children's Clinical Hospital in Vinnytsia, Ukraine. The study methodology was approved by the Ethics Committee of the Vinnytsya National Pirogov Memorial Medical
University (Protocol №4). Informed consent was obtained from the parents of all newborns for their blood sampling.

In total, 65 newborns were enrolled in this study. Thirty-five of the 65 newborns (examination group) had unexplained prolonged indirect hyperbilirubinemia. The remaining 30 newborns (control group) were healthy neonates and had physiological jaundice during their follow-up period.

Study inclusion criteria were: breastfed newborns with duration of jaundice longer than 14 days of life, gestational age 37-41 weeks, body weight $>2500 \mathrm{~g}$, and total serum bilirubin concentration above $205 \mu$ mole $/ 1(12 \mathrm{mg} / \mathrm{dl})$.

Study exclusion criteria were as follows: blood group incompatibilities, haemolytic anemia, absence of congenital anomalies, hepatobiliary diseases, congenital and acquired infectious diseases including hepatitis, congenital hypothyroidism, congenital metabolic disorders, or delayed intrauterine development, as well as gestational period less than 37 weeks.

None of the newborns in the examination group or control group had a history of any important medical problem that developed in the postneonatal period. All newborns were breastfeeding.

For each newborn, the following records were reported: gestational age, mode of delivery (cesarean section versus vaginal delivery), Apgar score at birth, sex, anthropometric characteristics (body weight and body length), age, and clinical examination.

Blood samples for serum (AFP) measurement in the examination group were obtained when blood was drawn from the newborn for other tests necessary for evaluating the cause of jaundice: general blood test, biochemical (direct [dBil] and indirect [iBil]) bilirubin, alanine aminotransferase (ALT), and aspartate aminotransferase (AST). Blood samples from the control group were conveniently available from newborns who were admitted to our neonatology unit due to the puncture of a cephalohematoma. All blood samples were obtained by venipuncture and collected in sterile tubes, placed on ice, and immediately sent to the laboratory. After centrifugation of blood (1000 g for $30 \mathrm{~min}$ at $4{ }^{\circ} \mathrm{C}$ ), the plasma supernatant fluid was separated and stored at $-20^{\circ} \mathrm{C}$ until analyzed further.

Serum AFP measurements were made using

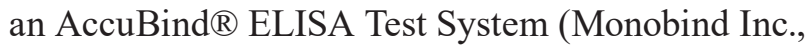
Lake Forest, USA). The quantitative determination of serum AFP concentration was made by a colorimetric microplate enzyme immunoassay. In the 
wells of the plates (on the walls of which were adsorbed antibodies to AFP), $25 \mu 1$ of standard solutions were added (AFP at $0 ; 5 ; 25 ; 50 ; 250 ; 500 \mathrm{ng} /$ $\mathrm{ml}$ ) along with $25 \mu \mathrm{l}$ of blood serum samples and $100 \mu$ l of anti-AFP enzyme reagent. The wells were stirred, covered with adhesive film, and incubated for $60 \mathrm{~min}$ at $25^{\circ} \mathrm{C}$ to form the AT-AG-AT-enzyme complex on the solid phase. The wells were rinsed to remove unbound reagents, and then $100 \mu \mathrm{l}$ of the chromogenic substrate was added. The wells were stirred again and incubated for $15 \mathrm{~min}$ at $25{ }^{\circ} \mathrm{C}$. The reaction was stopped with $50 \mu \mathrm{l}$ of stop solution and photometrated at $450 \mathrm{~nm}$ (differential filter of $630 \mathrm{~nm}$ ) on the STAT FAX 303/PLUS automatic analyzer which is an open system (USA). The sensitivity of the kit was $1 \mathrm{ng} / \mathrm{ml} \mathrm{AFP,} \mathrm{with} \mathrm{a} \mathrm{variation}$ factor $<10 \%$.

Statistical analysis was performed using the software package STATISTICA 6.0 (StatSoftInc., 2001, USA), "Microsoft Excel". Indicators that characterize the normal data distribution are presented as mean \pm standard deviation (SD). Nonparametric data are presented as the median (Me) and boundaries of the interquartile segment [Q1; Q3] (quartile). The Kolmogorov-Smirnov criterion was used to estimate the probability of differences between independent statistical groups with nonparametric distribution. The exact method of Fisher was used for the relative values (percentage). The difference in parameters was considered statistically significant at $P<0.05$. The Spearman rank correlation was used as a criterion for the statistical dependence between the parameters. The receiver operating characteristic (ROC) curve was plotted to determine the predictive value of serum AFP in newborns with prolonged jaundice. The results represent the value of the area under the curve (AUC) of the ROC curve based on the values of the sensitivity and specificity of the test, and indicate a $95 \%$ confidence interval (CI).

\section{Results and Discussion}

The gestational age, age at hospital admission, sex, and anthropometric characteristics of the newborns in the two study groups (examination and control) are presented in Table 1.

The mean gestation ages in the examination group and the control group were not statistically significantly different $(38.9 \pm 0.2$ - versus $39.2 \pm 0.2$ weeks, respectively, $(P>0.05))$. The mean age of the examination group at the time of hospital admission was significantly greater than that of the control group (20.1 \pm 0.7 versus $10.1 \pm 1.7$ days, $(P<0.05)$ ).

Among the newborns of both groups, there were significantly more boys: 26 boys (74.3\%) and 9 girls (25.7\%) in the examination group, and 24 boys $(80.0 \%)$ and 6 girls (20.0\%) in the control group $(P<0.05)$. According to percentile tables for normal growth, the physical development indicators were within the 10-90 percentiles. In newborns of the examination group, the mean body weight at birth was $3312.1 \pm 58.1 \mathrm{~g}$ and the length was $51.6 \pm 0.4 \mathrm{~cm}$. In the control group, the mean body weight was $3349.7 \pm 100.1 \mathrm{~g}$ and the length was $51.7 \pm 0.4 \mathrm{~cm}$. There were no significant differences in mean birth weight or mean length between the two groups $(P>0.05)$.

In most of the 35 newborns of the examination group, the state of adaptation after birth was considered satisfactory according to the Apgar score: 30 newborns $(85.7 \%)$ had $>8$ points at the first and fifth minutes of life. The other 5 newborns (14.3\%) had 6 points at the first minute and 8 points at the fifth minute.

Ta ble 1. Characteristics of the two study groups (mean $\pm S D$ ), $\%$

\begin{tabular}{lcc|c}
\hline \multicolumn{1}{c|}{ Characteristics } & Examination group, $(n=35)$ & Control group, $(n=30)$ & P value \\
\hline Gestational age, weeks & $38.9 \pm 0.2$ & $39.2 \pm 0.2$ & $>0.05$ \\
Age at admission, days & $20.1 \pm 0.7^{*}$ & $10.1 \pm 1.7$ & $<0.05$ \\
Boys & $26(74.3 \%)^{\#}$ & $24(80.0 \%)^{\#}$ & $<0.05$ \\
Girls & $9(25.7 \%)$ & $6(20.0 \%)$ & $>0.05$ \\
Birth weight, g & $3312.1 \pm 58.1$ & $3349.7 \pm 100.1$ & $>0.05$ \\
Length, cm & $51.6 \pm 0.4$ & $51.7 \pm 0.4$ & $>0.05$
\end{tabular}

*a significant difference versus the control group $(P<0.05)$; " a significant difference versus the girls of the two study groups $(P<0.05)$ 
In the examination group, 25 newborns (71.4\%) had been transferred to the neonatology unit by the referral of a family physician. The reason for hospitalization was prolonged jaundice which had no tendency to decrease. The other 10 newborns (28.6\%) were transferred from the maternity hospital.

In 29 newborns $(83.0 \%)$ of the examination group, jaundice appeared on the $3^{\text {rd }}$ day of life, and in the other 6 newborns (17.0\%) on the $4^{\text {th }}$ day of life. In all newborns of the control group, jaundice appeared on the 3rd day of life.

The risk factors for the development of prolonged jaundice in newborns are complications during pregnancy and childbirth, the presence of gynecological and extragenital pathology in mothers, and onerous obstetric history, as well as prematurity, asphyxia, and cerebral ischemia [20-22]. The maternal age, weight, body mass index (BMI), numbers of pregnancies and prolonged delivery were significantly associated with bilirubin levels [23-25].

In order to determine the possible influence of perinatal factors on the development of prolonged jaundice in newborns, we investigated the features of pregnancy in the mothers of the newborns in this study. We found that the majority of newborns (21 newborns, 60.0\%, $P<0.05$ ) in the examination group were born from mothers who had a complicated pregnancy. Among the most frequent complications of pregnancy, were a threat of interruption in 11 mothers (52.3\%), acute respiratory viral infection in 6 (28.5\%), and anemia in $4(19.2 \%)(P<0.05)$.

In the examination group, 30 newborns (85.7\%) were born by vaginal delivery and 5 newborns (14.3\%) by caesarean section. All newborns of the control group were born by vaginal delivery $(P>0.05)$.
The neonatal period in all newborns of the examination group was complicated only by hyperbilirubinemia. Activity and congenital reflexes were present, and all newborns actively sucked their mother's breasts. Except for jaundice, all patients had no other pathological symptoms. The dimensions of parenchymal organs (liver and spleen) were normal for the age, according to clinical and ultrasound data. The color of urine and feces had a physiological character was physiologically normal.

Thus, the risk factors for the development of prolonged jaundice of the newborn, according to our data are male sex and complicated obstetric history.

The hematological and biochemical parameters of the study groups are shown in Table 2 .

Based on the biochemical parameters, we noted that often the total bilirubin values were $>250 \mu$ mole/l, (15 mg/dl) in newborns with prolonged jaundice due to the indirect fraction: mean total bilirubin levels were $255.4 \pm 12.5 \mu$ mole/l (indirect $=240.1 \pm 12.3 \mu \mathrm{mole} / \mathrm{l}$, direct $=12.1 \pm 2.1 \mu \mathrm{mole} / \mathrm{l}$ ) $(P<0.05)$. Blood counts were within the normal range in both groups $(P>0.05)$.

Analysis of the content of serum AFP showed that this indicator was 1.7 times higher in newborns of the examination group compared to newborns in the control group: $\mathrm{Me}=671.1[\mathrm{Q} 1=479.9$; $\mathrm{Q} 3=815.03] \mathrm{ng} / \mathrm{ml}$ and $\mathrm{Me}=401.0[\mathrm{Q} 1=284.9$; $\mathrm{Q} 3=684.0] \mathrm{ng} / \mathrm{ml}$, respectively, $(P<0.05)$.

Depending on the total serum bilirubin levels, the content of AFP was significantly higher in newborns of the examination group for total bilirubin $>250 \mu$ mole/l than for 201-250 $\mu$ mole/l $(\mathrm{Me}=626.2$ $[\mathrm{Q} 1=454.7 ; \mathrm{Q} 3=793.2]$ versus $\mathrm{Me}=450.6$ [Q1 = 386.1; Q3 = 682.0] ng/ml, $(P<0.05)$ (Table 3).

Ta ble 2. The hematological and biochemical parameters of the two study groups (mean $\pm S D$ )

\begin{tabular}{l|c|c|c}
\hline \multicolumn{1}{c}{ Indicators } & Examination group, $(n=35)$ & Control group, $(n=30)$ & $P$ value \\
\hline Hemoglobin $(\mathrm{g} / \mathrm{l})$ & $172.1 \pm 3.9$ & $172.5 \pm 5.1$ & $>0.05$ \\
Erythrocytes $\times 10^{12} / \mathrm{l}$ & $4.5 \pm 0.1$ & $4.7 \pm 0.1$ & $>0.05$ \\
Leucocytes $\times 10^{9} / \mathrm{l}$ & $7.7 \pm 0.48$ & $9.7 \pm 0.7$ & $>0.05$ \\
Total bilirubin, $\mu$ mole/l & $255.4 \pm 12.5^{*}$ & $161.2 \pm 17.7$ & $<0.05$ \\
Indirect bilirubin, $\mu$ mole/ 1 & $240.1 \pm 12.3^{*}$ & $153.8 \pm 11.0$ & $<0.05$ \\
Direct bilirubin, $\mu$ mole/l & $12.1 \pm 2.1$ & $14.7 \pm 2.1$ & $>0.05$ \\
ALT, Units/l & $14.05 \pm 8.7$ & $15.1 \pm 5.1$ & $>0.05$ \\
AST, Units/l & $17.1 \pm 5.5$ & $15.8 \pm 5.4$ & $>0.05$ \\
\hline
\end{tabular}

*a significant difference versus the control group $(P<0.05)$. ALT, alanine aminotransferase; AST, aspartate aminotransferase 
Table 3. Indicators of serum alpha-fetoprotein ( $\mathrm{ng} / \mathrm{ml}$ ) depending on the total serum bilirubin levels in newborns of the two study groups, Me [Q1; Q3]

\begin{tabular}{c|c}
\hline Total bilirubin, & Examination \\
$\mu$ mole/l & group, $(n=35)$ \\
\hline $201-250$ & $450.6[386.1 ; 682.0]$ \\
$>250$ & $626.2 *[454.7 ; 793.2]$
\end{tabular}

$*$ a significant difference versus levels of total bilirubin $=$ 201-250 Hmole/l, $(P<0.05)$

Correlation analysis established a strong direct correlation between the content of AFP and total serum bilirubin $>250 \mu$ mole/l in newborns of the examination group $\left(r_{\mathrm{xy}}=0.64, P<0.05\right)$. Also in the examination group, there was a somewhat weaker direct relationship between AFP and total serum bilirubin in the range of 201-250 $\mu$ mole/l $\left(r_{\mathrm{xy}}=0.34\right.$, $P<0.05)$.

In order to assess the prognostic value of a diagnostic method for assessing the risk of developing prolonged jaundice in newborns, ROC analysis was performed (Fig.).

The results of the ROC analysis confirmed that $\mathrm{AFP} \geq 571.7 \mathrm{ng} / \mathrm{ml}$ can identify newborns with prolonged jaundice with a sensitivity of $74.2 \%$ and a specificity of $74.5 \%$. The AUC was 0.870 (95\% CI

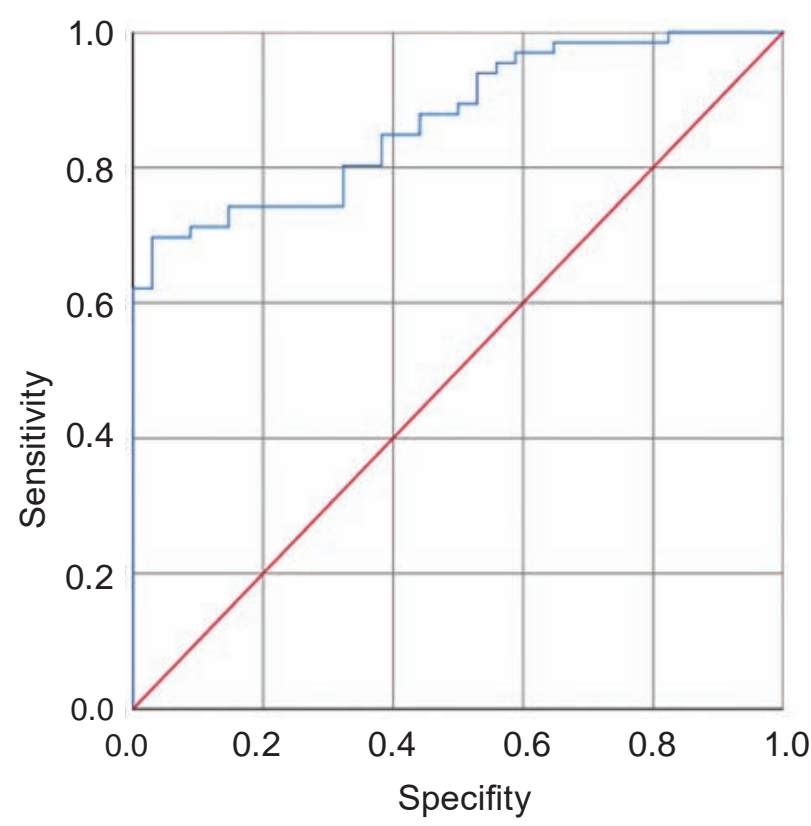

ROC curve of AFP content in blood serum for predicting the development of prolonged jaundice in newborns
$0.804,0.937$ ), which confirms the good quality of the AFP model $\geq 571.7 \mathrm{ng} / \mathrm{ml}$.

Our data suggest that in newborns with jaundice lasting longer than 14 days of life there were higher levels of serum AFP in comparison with nonjaundiced newborns. The mechanism by which postnatal AFP levels are elevated in jaundiced newborns remains to be clarified. We can speculate, that the increased content of serum AFP competes with albumin, displacing it from the binding zones with bilirubin and as a result of such competition, increases the concentration of indirect bilirubin which diffuses into body tissues, as well as into the enterohepatic circulation, which increases the load on the enzymatic and excretory capacity of the liver [26]. The practical focus of our work is to include an assessment of the serum content of AFP in the evaluation of newborns with duration of jaundice more than 14 days, that will differentiate the mechanisms that lead to a prolonged course of neonatal jaundice and start treatment in a timely manner.

Competing interests. The authors declare that they have no competing interests. The authors alone are responsible for the content and writing of the paper.

\section{АЛЬФА-ФЕТОПРОТЕЇН ЯК БІОХІМІЧНИЙ МАРКЕР ПРОГНОЗУВАННЯ ЗАТЯЖНОЇ ЖОВТЯНИЦІ В НОВОНАРОДЖЕНИХ ДІТЕЙ}

\author{
О. Г. Мазур, О. С. Яблонь, О. С. Рубіна, \\ М. М. Пугач, А. П. Коноплічька \\ Вінницький національний медичний \\ університет ім. М .І. Пирогова, Україна; \\ e-mail: alena523@ukr.net
}

Затяжна жовтяниця новонароджених $є$ поширеною патологією неонатального періоду. Останнім часом простежується тенденція до зростання числа новонароджених дітей із затяжною жовтяницею із пролонгацією після 14 діб життя. 3 огляду на поліетіологічність неонатальних жовтяниць $€$ необхідним пошук нових діагностичних маркерів для прогнозування розвитку затяжної жовтяниці в новонароджених, що дозволить визначити нові методи диференційованого підходу до діагностики неонатальних жовтяниць, а також зумовлюватиме зниження частоти цієї патології. 
Досліджували показники вмісту альфафетопротеїну (АФП) сироватки крові в дітей iз затяжною жовтяницею новонароджених. Встановили, що показник вмісту АФП сироватки крові вищий в 1,7 раза в дітей із затяжною жовтяницею новонароджених у порівнянні 3 дітьми 3 тривалістю жовтяниці до 14 діб життя: $671,1[479,9 ; 815,03]$ нг/мл та 401,0 [284,9; $684,0]$ нг/мл $(P<0,05)$. Вищим був вміст АФП сироватки крові в дітей із затяжною жовтяницею за рівня загального білірубіну сироватки крові більше 250 мкмоль/л: 626,2 [454,7; 793,2] нг/мл, що підтверджувалося сильним прямим кореляційним зв'язком $\left(r_{\text {ху }}=0,64, P<0,05\right)$.

Результати ROC-аналізу підтвердили, що вміст АФП $\geq 571,7$ нг/мл може ідентифікувати новонароджених iз затяжною жовтяницею 3 чутливістю 74,2\% і специфічністю 74,5\%. Площа під кривою (AUC) становить 0,870 (95\% ДІ 0,804; 0,937), що підтверджує хорошу якість моделі АФП $\geq 571,7$ нг/мл.

К л ю чо в і с ло в а: альфа-фетопротеїн, затяжна жовтяниця, новонароджені, білірубін.

\section{References}

1. Jardine LA, Woodgate P. Neonatal jaundice. Am Fam Physician. 2012; 85: 824-825.

2. Bhutani VK, Stark AR, Lazzeroni LC, Poland R, Gourley GR, Kazmierczak S, Meloy L, Burgos AE, Hall JY, Stevenson DK. Predischarge screening for severe neonatal hyperbilirubinemia identifies infants who need phototherapy. J Pediatr. 2013; 162(3): 477-482.

3. Maisels MJ, Clune S, Coleman K, Gendelman B, Kendall A, McManus S, Smyth M. The natural history of jaundice in predominantly breastfed infants. Pediatrics. 2014; 134(2): e340-e345.

4. Fawaz R, Baumann U, Ekong U, Fischler B, Hadzic N, Mack CL, McLin VA, Molleston JP, Neimark E, Ng VL, Karpen SJ. Guideline for the evaluation of cholestaticjaundice in infants: joint recommendations of the North American Society for pediatric gastroenterology, hepatology, and nutrition and the European Society for pediatric gastroenterology, hepatology, and nutrition. J Pediatr Gastroenterol Nutr. 2017; 64(1): 154168.

5. Pan DH, Rivas Y. Jaundice: Newborn to Age 2 Months. Pediatr Rev. 2017; 38(11): 499-510.

6. Hodgson JM, van Someren VH, Smith C, Goyale A. Direct bilirubin levels observed in prolonged neonatal jaundice: a retrospective cohort study. BMJ Paediatr Open. 2018; 2(1): e000202.

7. Bhutani VK, Stark AR, Lazzeroni LC, Poland R, Gourley GR, Kazmierczak S, Meloy L, Burgos AE, Hall JY, Stevenson DK. Predischarge screening for severe neonatal hyperbilirubinemia identifies infants who need phototherapy. J Pediatr. 2013; 162(3): 477-482.

8. Gottesman LE, Del Vecchio MT, Aronoff SC. Etiologies of conjugated hyperbilirubinemia in infancy: a systematic review of 1692 subjects. BMC Pediatr. 2015; 15: 192.

9. Fujiwara R, Maruo Y, Chen S, Tukey RH. Role of extrahepatic UDP-glucuronosyltransferase 1A1: Advances in understanding breast milkinduced neonatal hyperbilirubinemia. Toxicol Appl Pharmacol. 2015; 289(1): 124-132.

10. Chiou FK, Ong C, Phua KB, Chedid F, Kader A. Conjugated hyperbilirubinemia presenting in first fourteen days in term neonates. World $J$ Hepatol. 2017; 9(26): 1108-1114.

11. Greco C, Arnolda G, Boo NY, Iskander IF, Okolo AA, Rohsiswatmo R, Shapiro SM, Watchko J, Wennberg RP, Tiribelli C, Coda Zabetta CD. Neonatal Jaundice in Low- and Middle-Income Countries: Lessons and Future Directions from the 2015 Don Ostrow Trieste Yellow Retreat. Neonatology. 2016; 110(3): 172180.

12. Parvathamma PA, Brockbank EP, Abourahma Y. Three-year experience with prolonged neonatal jaundice screening in a district general hospital. Int J Contemp Pediatr. 2017; 4(1): 1-4.

13. Flaherman VJ, Maisels MJ. ABM Clinical Protocol \#22: Guidelines for Management of Jaundice in the Breastfeeding Infant 35 Weeks or More of Gestation-Revised 2017. Breastfeed Med. 2017; 12(5): 250-257.

14. Scrafford CG, Mullany LC, Katz J, Khatry SK, LeClerq SC, Darmstadt GL, Tielsch JM. Incidence of and risk factors for neonatal jaundice among newborns in southern Nepal. Trop Med Int Health. 2013; 18(11): 1317-1328.

15. Zhou S, Wang Z, He F, Qiu H, Wang Y, Wang H, Zhou J, Zhou J, Cheng G, Zhou W, $\mathrm{Xu} \mathrm{R}$, Wang M. Association of serum bilirubin in newborns affected by jaundice with gut microbiota dysbiosis. J Nutr Biochem. 2019; 63: 54-61. 
16. Tuzun F, Kumral A, Duman N, Ozkan H. Breast milk jaundice: effect of bacteria present in breast milk and infant feces. J Pediatr Gastroenterol Nutr. 2013; 56(3): 328-332.

17. Paul SP, Barnden J, Adams HL. Objective Assessment of Stool Color in Neonates with Prolonged Jaundice. Indian J Pediatr. 2017; 84(5): 415-416.

18. Martín V, Maldonado-Barragán A, Moles L, Rodriguez-Baños M, Campo RD, Fernández L, Rodríguez JM, Jiménez E. Sharing of bacterial strains between breast milk and infant feces. J Hum Lact. 2012; 28(1): 36-44.

19. Kuzdan C, Çoban AÇ, İnce Z, Can G, Türkoğlu Ü. The umbilical cord alpha-fetoprotein levels for predicting hyperbilirubinemia in term neonates. J Matern Fetal Neonatal Med. 2014; 27(3): 265-269.

20. Yablon O, Mazur O. Alpha-fetoprotein and prolonged neonatal jaundice. Neonatol Surg Perinat Med. 2016; VI(4(22)): 23-27. (In Ukrainian).

21. Lenchenko AV. Clinical and paraclinical characteristics of children with prolonged conjugational jaundice. Perinatol Pediatr. 2013; 3(55): 9-12. (In Ukrainian).
22. Sharma S, Dhakal I. Complications among Mothers and New Born Due to Delivery Process in Rupandehi District Nepal. J Nepal Health Res Counc. 2018; 16(2): 190-194.

23. Tavakolizadeh R, Izadi A, Seirafi G, Khedmat L, Mojtahedi SY. Maternal risk factors for neonatal jaundice: a hospital-based cross-sectional study in Tehran. Eur J Transl Myol. 2018; 28(3): 7618.

24. Norman M, Åberg K, Holmsten K, Weibel V, Ekéus C. Predicting Nonhemolytic Neonatal Hyperbilirubinemia. Pediatrics. 2015; 136(6): 1087-1094.

25. Özdek S, Kul M, Barış Akcan A, Çekmez F, Aydemir G, Aydınöz S, Karademir F, Süleymanoğlu S.The effect of the pre-pregnancy weight of the mother and the gestational weight gain on the bilirubin level of term newborn. J Matern Fetal Neonatal Med. 2016; 29(15): 2434-2437.

26. Garosi E, Mohammadi F, Ranjkesh F. The relationship between neonatal jaundice and maternal and neonatal factors. Iranian J Neonatol. 2016; 7(1): 37-40. 